\title{
Legal Accounting: A New Method for Accounting Survey
}

\author{
Dr. Binod Shah \\ Faculty of Management, R.R.M. Campus, Janakpurdham, Tribhuvan University
}

\begin{abstract}
Forensic accounting is not a new concept though it has grown in popularity in recent years. It has come into limelight due to rapid increase in financial frauds and white - collar crimes. Forensic accounting is the combination of accounting, auditing and investigative skills. It provides investigative functions and litigation support services to understand the depth and width of the financial scams happening in any economy. This research paper discusses the concept and history of forensic accounting, the need for it and services rendered by forensic accountants on the basis of secondary data collected from various sources.
\end{abstract}

Keywords: Financial Scams, Forensic accounting, Fraud, Investigation, Investigative Accounting, Litigation, White Collar Crimes

\section{Introduction}

Over the last decade, the number of white collar crimes committed in the world has been increasing due to accounting frauds. Many cases of financial statement misrepresentation have been reported, and to that extent, affected companies like Enron, World Com, Adelphia, Global Crossing, Xerox, Qwest, and many others like Cendant, Lincoln Savings, ESM, Anicom, Waste Management, and Sunbeam and their auditors have gone down (Albrecht,2005). In effect, stakeholders, most especially the shareholders were greatly affected. Numerous financial frauds from the past and the beginning of the century have seriously disrupted the faith of numerous users in financial information contained in financial statements. The greatest frauds of the users of financial information and primarily investors have been committed by exhibiting falsified financial statements. Due to complicated nature of these problems, forensic accountants are needed to diagnose the accounting errors used to mislead the public, they then need to present the information to the courts or to the public.

Forensic accounting is the combination of accounting, auditing and investing skills. It is the application of a specialized knowledge and specific skills to identify transactions which are not authentic and gather the evidence regarding the same. It involves in investigating and analyzing financial evidence, developing computerized applications to assist in the analysis and presentation of financial evidence, communicating the findings in the form of reports and assisting in legal proceedings. Initially, forensic accountants were used by government agencies to uncover and investigate leading frauds. Nowadays, forensic accountants are usually retained by lawyers, police forces, insurance companies, governmental regulatory bodies and agencies, banks, courts, and the business community.

\section{Objectives of the Study}

Recent cases of frauds and financial scams in all over the world require more professionalism in accounting and finance. Growing incidence of financial fraud have given rise to the field of forensic accounting, a specially practice area of accounting that focuses on uncovering fraud. A forensic accounting engagement often involves a detailed assessment of a company's accounting system and processes to determine whether or not the numbers that are presented reflect reality. In view, the objectives of the paper are:

- To understand the concept of forensic accounting.

- To review the history of forensic accounting.

- To discuss the need of forensic accounting.

- To highlight the services rendered by forensic accountants.

\section{Methodology of the Study}

The present paper is of conceptual nature and purely based on information from secondary sources. This paper is based on the review of existing literatures on forensic accounting. For this purpose, various articles on forensic accounting at national and international level, working papers, e-papers, and reports on newspapers are reviewed carefully. Thus, it is a Review Research. This paper is a theoretical analysis of concept of forensic accounting, history of forensic accounting, need of forensic accounting and services provided by forensic accountants.

\section{Concept of Forensic Accounting:}

Forensic accounting includes the use of accounting, auditing and investigative skills to assist in legal matters. It consists of two major components : litigation services that recognise the role of an accountant as an expert consultant and investigative services that use a forensic accountant's skills and may require possible court room testimony (Bhasin, 2007).

According to American Institute of Certified Public Accountants (AICPA) "Forensic accounting is the application of accounting principles, theories, and discipline to facts or hypotheses at issues in a legal dispute and encompasses every branch of accounting knowledge". Crumbley et. al. (2005) define forensic accounting as the action of identifying, recording, setting, extracting, sorting, reporting and verifying past financial data or other accounting activities for setting current or prospective legal disputes or using such past financial data for projecting potential financial data to settle legal disputes. Forensic accounting, sometimes, called investigative accounting is 
the application of an expert knowledge and specific skills to spot transactions which are not authentic and gather the evidence regarding the same. It is used for fraud examination and fraud examination covers fraud allegations from inception to disposition, including obtaining evidence, interviewing, writing reports and testifying (Chakrabarti, 2014). The mixing of accounting, auditing and investigative skills creates the specialty, known as forensic accounting (Singh, 2012). It is a "specialty" practice area of accounting that explains engagements, which result from real or anticipated disputes or litigation.

Forensic accounting is when accountants use accounting, auditing and techniques to dig deep to undercover legal matters to fraud, to uncover illegal activities within a normal business practice, and some civil matters. They are involved in investigating and analyzing financial evidence, developing computerized applications to assist in the analysis and presentation of financial evidence, communicating, their findings in the form of reports, and assisting in legal proceedings. Forensic accounting consists the following two major components :

a) Litigation support: Litigation support is when the forensic accountant presents the economic issues related to any existing or pending litigation. This means the accountant must assess the damages sustained by the parties involved in a given legal dispute. The accountant can assist in resolving the dispute before the case even reaches court. If the dispute does end up going all the way to court then the forensic accountant can testify as an export witness. The forensic accountant is also present in the court room to cross-examine the opposing expert's testimony as well as the opposing export's damage.

b) Investigation: The second part of a forensic accountant's job is the investigation side, which is determining whether criminal matters like fraud have taken place. Forensic accountants will often use investigation on certain employee theft, securities fraud, insurance fraud, falsification of financial statements etc. The accountant is there to investigate and assist with the protection and recovery of assets. Forensic accountant may also recommend certain actions to be taken to minimize future risk of loss on each type of legal matter.

\section{History of Forensic Accounting}

Crumbley (2001) stated that a form of forensic accounting can be traced back to an 1817 court decision. The earliest reference was found in 1824 in an accountant's advertising circular in Glasgow, Scotland. He gave testimony in court and in arbitration proceedings. In the Egyptian times, 33003500 B.C., commercial transactions were recorded on clay tablets, these tablets were then sealed, and if the tablets were found to be tampered with later, investigations took place (Ghosh et al 2011). During the world war II, the Federal Bureau of Investigations (FBI) employed over 500 forensic accountants who were used to examine and monitor financial transactions. (Ziegenfuss, 2003).

Worldwide, Sherlock Holmes, the artificial character created by Sir Arthur Conan Doyle is considered to be the pioneer of forensic accounting. In India, "Kautilya" was the first person to mention the famous forty ways of embezzlement in his book "Arthashastra" during the ancient times. He was the first economist who openly recognized the need of forensic accountants. Similarly, Birbal, the scholar in the time of King Akbar, have explained different fraud examination methods. Some of his stories give the fraud examiner a brief idea about the Litmus test of investigation (Bhasin, 2007).

As the forensic accounting profession has grown over time, several publications have been produced to provide guidance. Maurice Peloubet, an accountant from New York, was probably the first to publish the phrase forensic accounting. In 1946, he published the article entitled "Forensic Accounting: Its place in Today's Economy". The book "Forensic Accounting: The accountant as an Expert Witness" was written by Francis C. Dykeman, in 1982. The American Institute of Certified Public Accountants (AICPA) issued practice Aid 7 in 1986, which outlines six areas of litigation services including: damages, anti-trust, accounting, valuation, general consulting, and analyses. The association of certified Fraud Examiners (ACFE) was founded in Texas in 1988 and the American College of Forensic Examiners was established in 1992. These institutions briefly explain need for trained forensic accountants and set the educational standards for training. Due to the growth of the profession, the American Board of Forensic Accountants was founded in March of 1997. Currently, there are various universities and colleges offering courses in forensic accounting.

\section{Need of forensic accounting:}

Forensic accounting is concerned with establishing the existence of fraud, determining the extent of damage or losses involved as a result of the fraud or crime and gathering of sufficient evidence for use by the courts of law to come up with a fair and judicial ruling for identification and / or prosecution. Over the past few years, there have been a number of relatively high profile matters involving the use of forensic accounting services. There is need of forensic accounting in the following areas:

1) Forensic accountants are engaged to detect fraud committed by employees, trace the assets created out of fund embezzlement, gather and review the evidence, and interview the employee alleged to have embezzled the funds.

2) With the help of forensic accountant, the settlement of retiring partner can be made.

3) Forensic accountants also take up cases relating to professional negligence. They are required to quantity the loss resulting from such professional negligence or deficiency in service.

4) Forensic accountants render arbitration and mediation services for the business community, since they undergo special training in the area of alternative dispute resolution.

5) Insurance companies engage forensic accountants to have an accurate assessment of claims to be settled. Similarly, policyholders seek the help of a forensic accountant when they need to challenge the claim settlement as worked out by the insurance companies.

6) Business firms engage forensic accountants to handle contract disputes, construction claims, product liability claims, infringement of patent and trademarks cases, liability arising from breach of contracts and so on.

7) Forensic accountants entertain cases pertaining to matrimonial disputes wherein their role is merely 
confined to tracing, locating and evaluating any form of asset involved.

\section{Services rendered by forensic accountants}

The accountant engaged in the forensic accounting is called forensic accountant. The role of forensic accountants varies from case to case. A forensic accountant has to analyze, interpret summarize and present complex, financial and business related issues for investigation. Forensic accountant carries out investigative accounting and provides litigation support. The services of forensic accountants are in great demand in the following areas :

1) Detection of fraud committed by employees : Where the employee pampers in fraudulent activities and is caught to have committed fraud, the forensic accountant tries to establish any assets created by them out of the funds defalcated and trying to find out the secret truth.

2) Criminal investigation: Forensic accountants are engaged for fraud and white - collar crime investigations for the purpose of civil and criminal actions.

3) Matters related with professional negligence: Forensic accounts also take up cases relating to professional negligence. Whenever there is a breach of Generally Accepted Accounting Principles (GAAP) or auditing practices or ethical codes of any profession, forensic accounts are required to quantify the loss resulting from such professional negligence or deficiency in service.

4) Arbitration service : Forensic accountants render arbitration and mediation services for the business community, since they are trained in the area of alternative dispute resolution. They also resolve the matters related with partnership and corporation disputes.

5) Settlement of insurance claim : Insurance companies recruit forensic accountants to have a precise assessment of claims to be settled. Similarly, policyholders seek the help of a forensic accountant when they need to challenge the claim settlement as worked out by the insurance companies. A forensic accountant handless the claims relating to substantial loss policy, property loss due to different risks, loyality insurance and other type of insurance claims.

6) Dispute settlement : Business firms recruit forensic accountant for resolving the cases related with contract disputes, construction claims, product liability claims, infringement of patent and trade mark cases, liability arising from breach of contracts and so on.

7) Matrimonial dispute cases : Forensic accountants entertain cases pertaining to matrimonial disputes wherein their role is merely confined to tracing, locating and evaluating any form of asset involved.

\section{Conclusion}

It is noted in this paper that the field of forensic accounting is not a new concept, though it has grown in popularity in recent years. Growing incidences of financial fraud have given rise to the field of forensic accounting. A forensic accounting engagement often involves a detailed assessment of company's accounting system and processes to determine whether or not the numbers that are presented reflect reality. The public fraud scandals, the internet and other technological advances and even the threat of terrorists have created a large demand for the skills and services provided by forensic accountants. Forensic accountants are in high demand because they play a critical role in an investigation of suspected financial scandals and misappropriation of assets. The objectives set out at the beginning include the examination of concept of forensic accounting, the services provided by forensic accountants and need for forensic accounting. In this study, the concept of forensic accounting, the history of forensic accounting, need of forensic accounting and services provided by forensic accountants have been considered. The finding revealed that forensic accounting is one of the newest ever growing areas in accounting. The various agencies fighting corruption world wide will need to engage the service of forensic accountants in reducing fraudulent activities and installing fraud proof control system.

\section{References}

[1] Bhasin, M. (2007), Forensic Accounting : A New Paradigm for Niche Consulting. The Chartered Account, ICAI, New Delhi

[2] Chakrabarti, M. (2014). Problems and Prospects of Forensic Accounting Profession in India. International Journal of Informative \& Futuristic Research, ISSN 2347-1697 Vol. 2. No 1.

[3] Crumbley, D.L. (2001). Forensic Accounting : Older than you think JTA Vol 2. No.2

[4] Crumbley, D.L., Heitger, L.E., and Smith, G.S. (2005), Forensic and Investigative Accounting. $\mathrm{CCH}$ Group. Chicago.

[5] Ghosh I. and Banerjee, K.K. (2011)2, Forensic Accounting - Another feather in the Hat of Accounting. The Chartered Accountant, ICAI, New Delhi.

[6] Singh P. (2012), Forensic Accounting Concept in India. International Journal of Trade and Commerce. IIARTC January - June, Vol. 1. No. 1.

[7] Ziegenfuss, D. (2003). Forensic Accountants : Hot Old Profession. www.odu.edu / ao / instad / quest / Forensic Account.html.online posting 